\title{
Obtaining particulate agglomerates from the recycling of multilayer containers and low density polyethylene
}

\section{Obtención de aglomerados particulados a partir del reciclaje de envases multicapa y polietileno de baja densidad}

\author{
ENRÍQUEZ-PÉREZ, Ma. Angeles $\dagger^{1}$, ROSALES-DAVALOS, Jaime ${ }^{2}$ and CASTREJÓN-SÁNCHEZ, \\ Víctor Hugo ${ }^{1}$
}

${ }^{1}$ Tecnológico de Estudios Superiores de Jocotitlán, Departamento de Ingeniería en Materiales

${ }^{2}$ Tecnológico de Estudios Superiores de Jocotitlán, Departamento de Ingeniería Mecatrónica

ID $1^{\text {st }}$ Author: Ma. Angeles, Enríquez-Pérez / ORC ID: 0000-0002-2280-0661, Researcher ID Thomson: H-9399-2018

ID $1^{\text {st }}$ Co-author: Jaime, Rosales-Davalos / ORC ID: 0000-0002-9059-6093, CVU CONACYT ID: 812961

ID $2^{\text {nd }}$ Co-author: Víctor Hugo, Castrejón-Sánchez / ORC ID: 0000-0002-0112-5388, Researcher ID Thomson: C-90772015, CVU CONACYT ID: 235470

DOI: $10.35429 / J U S D .2021 .21 .7 .1 .6$

Received: July 10, 2021; Accepted October 30, 2021

\begin{abstract}
Resumen
Actualmente, ha crecido el interés y la necesidad de innovar nuevos materiales mediante el uso de materiales de desecho, que cumplan con características físicas, químicas y mecánicas similares o mejoradas de los materiales a los cuales sustituirán. Durante la presente investigación se recolectaron Envases Multicapa (EM) y de Polietileno de Baja Densidad (PEBD), se obtuvieron aglomerados particulados con diferentes proporciones, se determinó la densidad aparente, absorción de agua, masa, volumen, comportamiento al calor, ángulo de contacto, mecanizado y ensayos a la compresión. Con el objetivo de evaluar las proporciones $\mathrm{p} / \mathrm{p}$ en las propiedades. La ventaja del material obtenido es que no generan residuos y son 100\% reciclables. La proporción 90:10 es la que se podría usar en la industria de la construcción como muros falsos, con un módulo de ruptura de $52.7 \mathrm{~N} / \mathrm{mm}^{2}$ y un esfuerzo de compresión de 32.9 MP, debido a que puede ser mecanizado sin alterar sus características físicas; mientras que las proporciones 85:15 y 80:20 al no poderse mecanizar podrían usarse como soporte flotante con un catalizador fotocatalizador, debido a que estos aglomerados poseen estabilidad dimensional al estar en contacto con el agua.
\end{abstract}

Proporción p/p, Aglomerados, Ensayo de compresión

\begin{abstract}
Currently, the interest and the need to innovate new materials through the use of waste materials has grown, which meet similar or improved physical, chemical and mechanical characteristics of the materials they will replace. During the present investigation, Multilayer Containers (EM) and Low Density Polyethylene (LDPE) were collected, particulate agglomerates with different proportions were obtained, the apparent density, water absorption, mass, volume, heat behavior, angle were determined. contact, machining and compression tests. With the objective of evaluating the proportions $\mathrm{p} / \mathrm{p}$ in the properties. The advantage of the material obtained is that they do not generate waste and are $100 \%$ recyclable. The 90:10 ratio is the one that could be used in the construction industry as false walls, with a modulus of rupture of $52.7 \mathrm{~N} / \mathrm{mm} 2$ and a compressive stress of 32.9 MP, because it can be machined without altering its characteristics. -physical houses; While the 85:15 and 80:20 proportions, since they cannot be machined, could be used as a floating support with a photocatalyst catalyst, due to the fact that these agglomerates have dimensional stability when in contact with water.
\end{abstract}

w/w ratio, Agglomerates, Compresion test

Citation: ENRÍQUEZ-PÉREZ, Ma. Angeles, ROSALES-DAVALOS, Jaime and CASTREJÓN-SÁNCHEZ, Víctor Hugo. Obtaining particulate agglomerates from the recycling of multilayer containers and low density polyethylene. Journal of Urban and Sustainable Development. 2021. 7-21: 1-6

\footnotetext{
*Correspondence to the author (e-mail: angelenriper@gmail.com)

$\dagger$ Researcher contributing as first author
} 


\section{Introduction}

The evolution of humanity is analyzed in social, cultural or technological aspects; such evolution has always been conditioned by the discovery of new materials with better properties than those that already exist, the development of technologies focused on production processes is needed, in order to reduce material losses and the creation of new materials (Tenorio, Moya, \& Camacho, 2012).

For example, manufacturing lighter construction materials, smaller in size and with good mechanical and physical properties, low cost and easy to use, the important thing is the benefit they can bring to the environment with the purpose of finding sustainable solutions to the environmental problems that arise (Nemli, Ozturk, \& Aydin, 2005).

By definition a chipboard is a composite type material that is generally made up of a resin (matrix), bonded with a fiber or wood (reinforcement) (Gaitán, Fonthal, \& Ariza, 2016). In some cases, they are manufactured with mineral, glass, carbon and aramid fibers; however, synthetic fibers have been replacing synthetic fibers with natural fibers (Nguong, Lee, \& Sujan, 2013). Although, branches and small-sized roundwood from primary forest harvesting and residues from forest industries, such as sawmills, carpentries, plywood factories, among others, are also used as raw material (Rangel, Moreno, Trejo, \& Valero, 2017).

The world population consumes approximately 188 million tons of wood per year (Hernández T \& Hernández F., 2020), if the rate of wood fiber consumption and population growth remains constant the demand for wood will increase which could increase deforestation, causing an environmental problem (Zambrano, et al., 2013) (González, Jaramillo, Pérez, \& Sablón, 2018). For this reason, the substitution of the raw material for a more accessible one that does not affect the ecosystem is analyzed (Contreras, et al., 2010) (Akkus, Akbulut, \& Candan, 2019).

Recycling being an alternative, it allows the recovery of various materials, not only of wood origin, multilayer containers could be used to obtain agglomerates.
Multilayer containers are formed by several layers of polyethylene, aluminum and cardboard, being the polyethylene the binding agent that allows by the action of heat to keep the materials together (Obando \& Escobar, 2009). Therefore, this work evaluates the influence on the physical-mechanical properties, when the agglomerates are reinforced with low density polyethylene, in different proportions w/w, in order to analyze the possible applications, they can be used in the construction industry as false walls or as supports in photocatalysis.

\section{Methodology}

\subsection{Obtaining agglomerates}

To obtain the agglomerates, post-consumer multilayer (MS) and low density polyethylene (LDPE) containers were collected, washed and dried at room temperature. The raw material was ground with a grinder to obtain a particle size of $5 \mathrm{~mm}$ for the MS and $1 \mathrm{~cm}$ for the LDPE. Subsequently, the raw material is weighed; Table 1 shows the w/w ratios that were experimented to obtain the agglomerates. The raw material is placed inside a mold with dimensions of $23 \times 12.5 \times 5 \mathrm{~cm}$, which functions as a heating plate for thermoforming, controlled by a control system designed in Labview software.

The shredder and the heating plate were designed and built at the Tecnológico de Estudios Superiores de Jocotitlán. In thermoforming, agglomerates are obtained under the following operating conditions: heating time $60 \mathrm{~min}$, pressure 4 tons of axial compression at $180^{\circ} \mathrm{C}$; then the agglomerate is cooled to room temperature and extracted. The procedure described above has been previously reported (Enríquez Pérez, Rosales Davalos, López Ramirez, \& Castrejon Sanchez, 2017).

\begin{tabular}{|r|r|r|}
\hline Agglomerate & \multicolumn{1}{c}{$\%$ MS } & \multicolumn{1}{c|}{\begin{tabular}{r} 
LDPE \\
\multicolumn{1}{|r|}{}
\end{tabular}} \\
\hline 2 & 70 & 30 \\
\hline 3 & 80 & 25 \\
\hline 4 & 85 & 20 \\
\hline 5 & 90 & 15 \\
\hline 6 & 95 & 5 \\
\hline 7 & 100 & 0 \\
\hline
\end{tabular}

Table 1 Variation w/w between multilayer packaging (MS) and low-density polyethylene (LDPE) Source: Own Elaboration 
The physical-mechanical properties evaluated were: physical appearance, density, moisture content, water absorption, swelling, fireproofing, contact angle and compression tests, according to NMX-C- 013-1978 "Gypsum panels for partition walls, ceilings and fire protection" and ASTM D 1037-12 Standard Test Methods for Evaluating Properties of Wood-Base Fiber and Particle Panel Materials.

\section{Results}

\subsection{Physical Appearance}

Table 2 describes the physical characteristics of the agglomerates.

\begin{tabular}{|c|c|}
\hline Code & Appearance \\
\hline $\mathrm{A}_{1}-70: 30$ & $\begin{array}{l}\text { Heterogeneous matrix, hard to the touch, with } \\
\text { cracks on the faces. }\end{array}$ \\
\hline$A_{2}-75: 25$ & $\begin{array}{l}\text { Heterogeneous matrix, hard to the touch, with } \\
\text { cracks on the faces. }\end{array}$ \\
\hline A3-80:20 & $\begin{array}{l}\text { Homogeneous matrix, compact, hard to the } \\
\text { touch }\end{array}$ \\
\hline$A_{4-85: 15}$ & $\begin{array}{l}\text { Homogeneous matrix, compact, hard to the } \\
\text { touch }\end{array}$ \\
\hline A5-90:10 & $\begin{array}{l}\text { Homogeneous matrix, compact, hard to the } \\
\text { touch }\end{array}$ \\
\hline$A_{6}-95: 5$ & Heterogeneous matrix, hard to the touch \\
\hline$A_{7}-100: 0$ & $\begin{array}{l}\text { Homogeneous matrix, fragile to the touch, } \\
\text { spongy }\end{array}$ \\
\hline
\end{tabular}

Table 2 Characteristics of the agglomerates Source: Own Elaboration

The appearance of the agglomerates depends on the percentage by weight of ES and LDPE. The higher the proportion of plastic, the harder the matrix is, but the material does not interact with each other, presenting cracks on the faces, making it an unsuitable material for use as agglomerate. Therefore, we only worked with the materials that presented a homogeneous matrix, the agglomerates A380:20, A4-85:15 and A5-90:10 (see Figure 1).

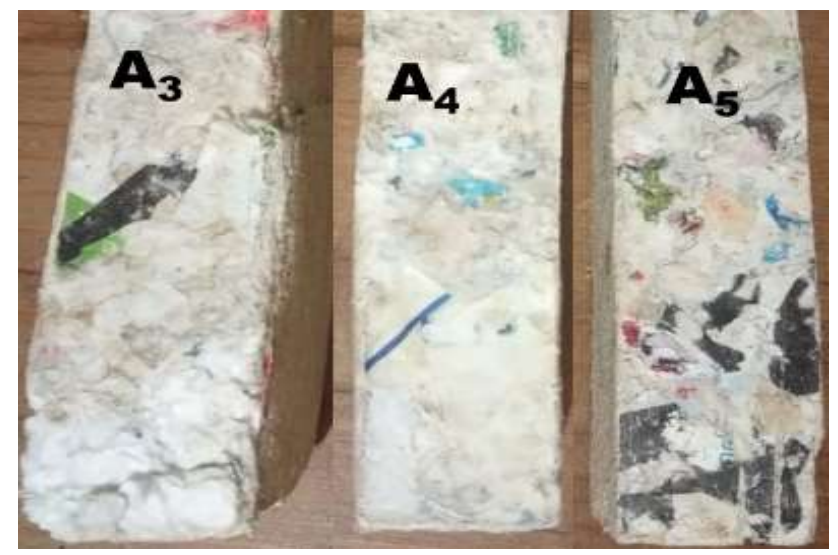

Figure 1 Agglomerates obtained Source: Own Elaboration

\subsection{Properties of the agglomerates}

The agglomerates obtained are lightweight materials; as the amount of plastic increases, the weight increases (see Table 3).

The agglomerates were left outdoors for one month to determine the moisture absorbed from the environment, as shown in Table 3, the moisture absorption is minimal, so they are suitable for outdoor use.

\begin{tabular}{|l|r|r|}
\hline Agglomerate & $\begin{array}{c}\text { Density } \\
\mathbf{K g}_{\mathbf{3}}\end{array}$ & Humidity \% \\
\hline $\mathrm{A}_{3}-80: 20$ & 947 & 3.3 \\
\hline $\mathrm{A}_{4}-85: 15$ & 752 & 2.9 \\
\hline $\mathrm{A}_{5}-90: 10$ & 651 & 2.9 \\
\hline
\end{tabular}

Table 3 Density and relative humidity of the agglomerates

Source: Own Elaboration

The water absorption and dimensional stability of an agglomerate is determined when the material is immersed in water for a period of time. Figure 2 shows the evolution of water absorption as a function of time (hours).

A3 initially absorbs $15.2 \%$ after $2 \mathrm{hr}$ and $16.7 \%$ after 24 hr. Meanwhile, A4 absorbs 24\% of water, then at 10 hours it increases to $35 \%$, this value being the maximum absorption of the material. Finally, A5, initially absorbs $8.7 \%$ and increases until it reaches a maximum of $14.2 \%$ after 10 hours. The agglomerates comply with ASTM D 1037, where the agglomerates can have an absorption between 25 and $60 \%$ between 2 and 24 hours.

There is no relationship between weight and absorption; some authors report that the greater the weight, the greater the absorption, but this behavior is not present in the materials obtained, since the material that absorbs less water is the one with the greater weight, although the most stable material is the one with the less weight. 


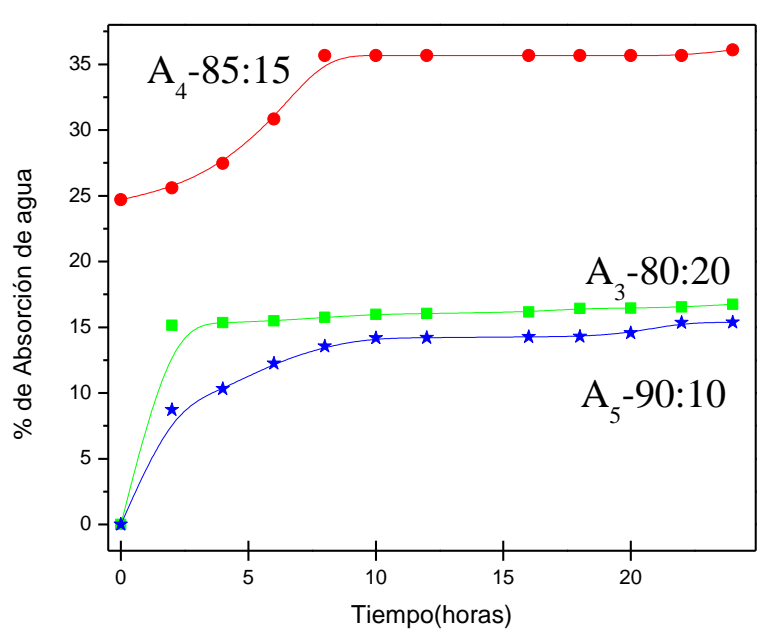

Figure 2 Percentage of water absorption. Source: Own Elaboration

When the moisture content is below the saturation point of the fibers (from 30\%), there is only an increase in weight and its volume remains practically constant (Volcuende, Parra, $\&$ Benlloch, 2005). The increase in volume of the agglomerates ranges from 4.2 to $6.1 \%$ (see Figure 3). Being A4 the one that presents the highest shrinkage, followed by A3 and then A5; although the agglomerates practically conserve their size, since the material remains stable in the presence of water. The change of volume in the materials is not visible to the naked eye.

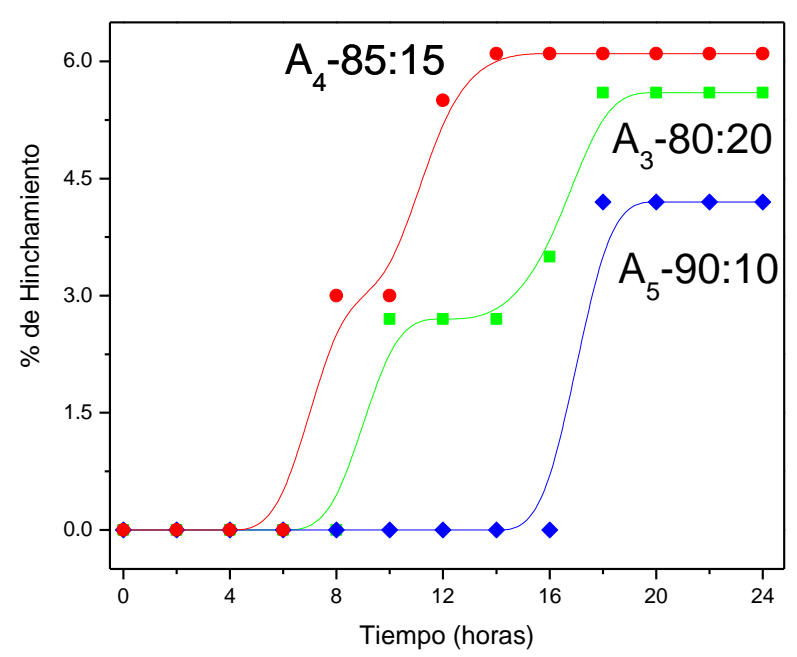

Figure 3 Percentage of swelling Source: Own Elaboration

The agglomerates were left submerged in water for a period of two months, the material floats in the water, despite the time there is no change in its appearance, when they were taken out and left to dry at room temperature, they did not have any modification in their structure.
The contact angle was determined by placing a drop (water, salts or acid) on the surface of the material, taking the time and calculating the angle formed between the surface and the drop, as shown in Figure 4.

Agglomerates are hydrophilic materials to water, it takes approximately $2 \mathrm{hrs}$ for a drop to deform. They show chemical resistance to attack with acids, lye and marine environment.

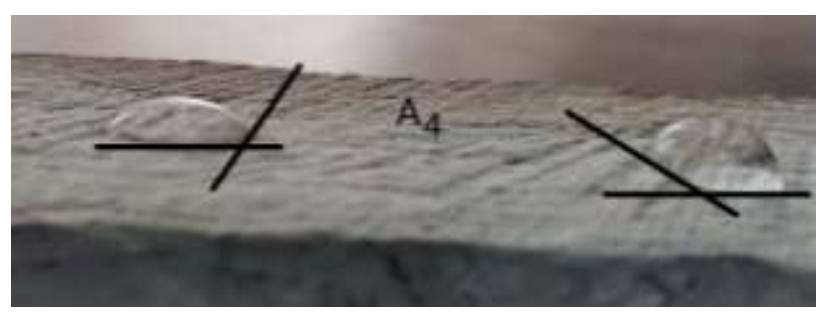

Figure 4 Contact angle of A4 with $\mathrm{H}_{2} \mathrm{O}$ and $\mathrm{HCl}$. Source: Own Elaboration

The agglomerates are fireproof materials, they do not propagate heat, they only carbonize. They have a weight loss between 14 to $17 \%$ of the material in a time of approximately 25-35 $\mathrm{min}$.

In addition, they can be cut and bound without altering their structure. Machining tests were carried out to determine if they can be drilled with a $1 / 4$ " drill bit, if they can support anchors and screws (see figure 5), the 6 faces were analyzed to determine if they can be assembled with screws, obtaining the following results:

- $A_{3}$, presented cracks when inserting the dowels, fractures occurred near the perforated area. It was not able to keep the dowel fixed, preventing the insertion of a screw. It has a brittle fracture, a modulus of rupture of $65.2 \mathrm{~N} / \mathrm{mm}^{2}$ and a compressive strength of $41 \mathrm{MPa}$.

$\mathrm{A}_{4}$ could be drilled, but the screw was not fixed, since there were small fractures on the lateral faces; therefore, it has a brittle fracture, with a modulus of rupture of $56.4 \mathrm{~N} / \mathrm{mm}^{2}$ and a compressive stress of $34.1 \mathrm{MPa}$.

- Finally, the $\mathrm{A}_{5}$ could be drilled, so that the dowels and therefore the bolt could be drilled out. It can be nailed, it behaves as a ductile material, its modulus of rupture is $52.7 \mathrm{~N} / \mathrm{mm}^{2}$ and a compressive stress of $32.9 \mathrm{MPa}$. 


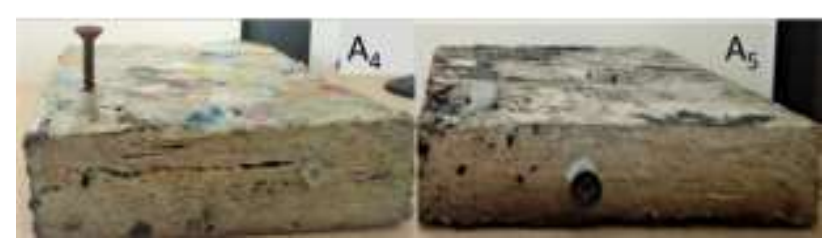

Figure 5 Screw test

Source: Own Elaboration

As the proportion of polymer in the agglomerates increases, both the modulus of rupture and compressive stress are higher; although this trend is not reflected in the machining tests, the opposite is true, the lower the proportion of LDPE, the more easily it can be machined.

\section{Conclusions}

Agglomerates were obtained, varying the proportion $(\mathrm{w} / \mathrm{w})$, between multilayer and LDPE containers.

However, only the proportions: $80: 20$, 85:15 and 90:10 are able to obtain agglomerates where the materials are integrated and homogeneous matrices are obtained.

Being, the A5 (90:10) a feasible alternative as an ecological agglomerate for closed and/or open places, to make divisions in interiors or as false walls, it can be mechanized without difficulty, it is light and absorbs $14.2 \%$ when it is immersed in water; due to its own characteristics they are electrical, thermal and acoustic insulating materials.

However, A4 and A3 (85:15 and 80:20, respectively) are not discarded, since they can be sawn and do not release material and are stable in water, they can be used as a floating support with a photocatalytic catalyst (composite) for the photocatalytic degradation of organic pollutants (e.g., dyes) present in wastewater.

\section{References}

Akkus, M., Akbulut, T., \& Candan, Z. (2019). Application of electrostatic powder coating and wood composite panels using a cooling method. Part 1: investigation of water intake, abrasion, scratch resistance, adhesion strength . Bioresources, 9557-9574.
Contreras, M. W., Will, V. S., Owen, C. M., Cloquell, B. C., Rondón, S. M., Barrios, P. E., Contreras, A. (2010). El Diseño Ambientalmente Integrado y el Ecodiseño en la elaboración de tableros aglomerados de partículas de bambú con adhesivo Fenol Formaldehido Integrated environme. Ecodiseño y sostenibilidad, 117-144.

Enríquez Pérez, M., Rosales Davalos, J., López Ramirez, R., \& Castrejon Sanchez, V. (2017). Aprovechamiento de residuos de envases multicapas para la elaboración de aglomerados. Ciencias Ambientales y Recursos Naturales, 27-31.

Gaitán, A., Fonthal, G., \& Ariza, C. (2016). Fabricación y propiedades físicas de aglomerados de Pennisetum purpureum schum, Philodendron longirrhizum y Musa acuminata. Revista Ciencias Técnicas Agropecuarias, 5-11.

González, R., Jaramillo, J., Pérez, Q., \& Sablón, C. (2018). Evaluación físico-mecánicas de tableros a base del Aserrín de Pigüe (Piptocoma discolor) y bagazo de caña de azúcar en Pastaza. Revista Amazónica y Ciencia y Tecnología, 95-104.

Hernández T, M., \& Hernández F., P. (25 de Octubre de 2020). Madera importada domina el mercado de México, pionero en el manejo forestal comunitario. Animal Politico, págs. 1-2.

Nemli, G., Ozturk, I., \& Aydin, I. (2005). Some of the parameters influencing surface roughness of particleboard. Building and Environment, 1337-1340.

Nguong, C., Lee, S., \& Sujan, D. (2013). A Review on Natural Fibre Reinforced Polymer composites. International Journal of Chemical, $33-44$.

Obando, J., \& Escobar, M. (2009). Modelación del proceso de recuperación parcial de envases de tretra pak. Revista EIA, 157-167.

Rangel, L., Moreno, P., Trejo, S., \& Valero, S. (2017). Propiedades de tableros aglomerados de partículas fabricados con madera de Eucalyptus urophylla . Maderas. Ciencia y tecnología, 373 - 386. 
Tenorio, C., Moya, R., \& Camacho, D. (2012). Propiedades físico-mecánicas de tableros terciados construidos con especies tropicales de plantaciones para uso estructur. Cerne, Lavras, 317-325.

Volcuende, M. O., Parra, C., \& Benlloch, J. (2005). Permeabilidad,porosidad y resistencia a la compresión de hormigones autocompactables. Materiales de construcción, 17-26.

Zambrano, L., Moreno, P., Muñoz, F., Durán, J., Garay, D., \& Valero, S. (2013). Tableros de partículas fabricados con residuos industriales de madera de Pinus patula. Madera y Bosques, 65-80. 